\title{
ПРОБЛЕМЫ И ПЕРСПЕКТИВЫ ТРАНСПЛАНТАЦИИ ТКАНЕЙ И ОРГАНОВ ЧЕЛОВЕКА
}

\author{
Усова Ольга Алексеевна \\ ФГБОУ ВО Тверской ГМУ \\ Минздрава России, г. Тверь
}

Аннотация: В статье рассматриваются вопросы трансплантологии тканей и органов человека, этические и правовые аспекты трансплантологии, развитие трансплантологии в России.

Ключевые слова: Трансплантация, регистр трансплантации, ксенотрансплантология, этико-правовые вопросы.

Введение. XX и начало ХХІстолетия ознаменовались большими успехами в трансплантологии. В современном мире трансплантология играет очень важную роль в сохранении и поддержании здоровья людей. Эта отрасль медицины активно развивается и совершенствуется. Согласно апокрифам первые операции по трансплантации органов и тканей были проведены ещё в III веке. Святые Косма и Дамиан успешно пересадили ногу недавно умершего эфиопа своему пациенту. Болонский хирург эпохи Возрождения Гаспар Тальякоцци (1545-1599), занимался аутотрансплантацией кожи, отмечал в своих работах, что при пересадке человеку фрагмента чужой кожи всегда происходит отторжение. Первую в мире операцию по трансплантации провел хирург Ю.Ю. Вороной (1895-1961) в г. Херсоне. 26-летней женщине 3 апреля 1933 г. была пересажена почка скончавшегося 60-летнего мужчины. Больная прожила с чужой почкой более двух суток. Одним из родоначальников мировой трансплантологии считается советский ученый Владимир Петрович Демихов (1916- 1998) - биолог, физиолог, хирург-экспериментатор. В настоящее время ежегодно в мире выполняется примерно 100 тысяч трансплантаций органов и более 200 тысяч - тканей и клеток человека.

Цель: изучение основных современных проблем трансплантации органов и тканей у человека, оценка перспективы этой отрасли медицины.

Задачи: изучить литературу. Познакомиться с историей трансплантации и успехами медицины в трансплантологии, оценить перспективу ее развития. Сделать вывод о проблемах и перспективах пересадки органов и тканей у человека. 
Методы: изучение медицинской литературы и статей, обработка информации и обобщение.

В современном мире трансплантология в медицине занимает не последнее место. Эта отрасль берет свое начало с 1931 года ( профессор Ю.Ю. Вороной выполнил первую трансплантацию от человека к человеку) и активно развивается до сих пор. Но, врачи, добиваясь определенных успехов иногда сталкиваются с некоторыми проблемами. Например, возникают правовые и этические проблемы, для решения которых необходимо взаимодействие медиков, психологов и правоведов.

В истории развития трансплантологии выделяются 2 периода:

1. удаление хирургическим путем патологических измененных тканей и органов;

2. работа по удалению органа или ткани утратившего свои функции и пересадка на его место здорового органа.

Изначально опыты проводились на животных: в 1902 году венский хирург Э. Ульман доложил о первой трансплантации почки и провёл эксперимент с козой, пересадил ей на шею почку собаки. Позднее медицина впервые провели пересадку органа от человека к человеку в 1931. В течение следующих двух десятилетий многие учёные-врачи пытались провести трансплантацию почки в разных странах. Долгожданный успех пришел в 1954г, когда в Бостоне Дж. Мюррей и Дж. Мерил выполнили трансплантацию почки от мужчины его однояйцовому близнецу, который прожил после этого более 20 лет. Трансплантация таких органов, как сердце и легкие, состоялась уже гораздо позже, в 90-х годах прошлого столетия. [1]

Разумеется, наряду с успехами в трансплантологии есть и ряд проблем, связанных с различными сферами. Важнейшая, на мой взгляд, проблема финансового характера. Данные операции весьма дорогостоящие, и далеко не каждый человек может себе их позволить.

Следующая проблема, также весьма важная, - малое количество донорских органов и тканей, вследствие чего люди годами ждут операции. И, к сожалению, многие не дожидаются.

Этико-правовые вопросы трансплантации касаются оправданности и неоправданности пересадки жизненно важных органов в клинике, а также проблематики взятия органов у живых людей и трупов. Пересадка органов от живого человека, безусловно, нанесет определенный вред его здоровью. Поэтому в разделе живого донорства идет оценка пользы для реципиента и 
вреда для донора. [2] В России по законодательству в качестве живого донора может выступать только родственник реципиента и обязательным условием, как для донора, так и для реципиента является добровольное информированное согласие на проведение трансплантации. [3] В результате чего более распространен метод пересадки органов трупов. Но здесь появляется проблема религиозного характера и проблема добровольного волеизъявления о взятии органов после смерти. Такое разрешение люди оставляют достаточно редко. Хотя их родственники могут дать такое согласие после смерти человека.

Трансплантация тканей и органов в России находится на низком уровне по сравнению с европейскими странами, потому что регулирование операционных вмешательств, связанных с пересадками органов и тканей является правовой проблемой государства. Перспектива развития этой отрасли в нашей стране есть, но только с созданием законодательной базы. [4]

Важно понимать, что перспектива развития трансплантологии напрямую связана с перспективой развития и других отраслей медицины: хирургии, иммунологии, анестезиологии, генетики и реаниматологии.

Религиозный аспект также влияет на разрешение трансплантации органов человека. Нужно отметить, что православная церковь дает согласие на пересадку, так как считает, что это помогает тяжело больным людям вылечиться. Трансплантацию органов от живого человека разрешают только с его согласия и полного разъяснения донору последствий операции. Римскокатолическая церковь считает, что донорство в трансплантологии - это акт милосердия и нравственный долг. В иудаизме запрещено вскрытие трупа, но трансплантация возможна от мертвого человека, если при жизни им было дано согласие. Пересадку производят с условием, что тело донора не будет изуродовано. В буддизме пересадка органов считается возможной только от живого донора при условии, что это было даром больному. В исламе же категорически запрещена любая трансплантация органов. [5]

Для решения проблем и для дальнейшего перспективного развития трансплантологии в целом был создан единый регистр трансплантации (в июне 2012 года в Белоруссии принят закон о создании такого регистра), в который занесены данные:

- о людях, которые нуждаются в трансплантации каких-либо органов и тканей; 
- о людях, которым сделали пересадку и необходимо следить за динамикой их самочувствия;

- о людях, которые подписали несогласие на забор органов и тканей после их смерти.

Единый регистр трансплантации позволил ускорить процесс оказания медицинской помощи людям, нуждающимся в донорских органах или тканях.

Одной из основных проблем трансплантологии является слишком короткое время хранения донорских органов и тканей. При правильных условиях хранения печень может находиться вне человеческого тела не более 15 часов, почка - не более 48 часов, сердце - до 4х часов. Если эти условия хранении органов не соблюдаются, то начинается отмирание клеток. Соответственно назревает следующая проблема: малый географический радиус, куда в короткое время успеет доехать донорский орган. Но и эту проблему пытаются решить ученые. Американская команда учёных представила результаты своего нового подхода, который способен увеличить время хранения трансплантатов. Было заявлено, что их устройство презервации способно сохранять целостность клеток сердечной мышцы кардиомиоцитов - более 24 часов, что на 20 часов увеличивает время хранения донорского сердца [6]. Устройство использует перфузию для поддержания питания клеток и насыщения их кислородом. Подобный процесс замедляет апоптоз клеток, что непосредственно увеличивает время жизни трансплантатов и расширяет географическую зону доставки донорского сердца.

Для достижения успехов раздела медицины - трансплантологии, нужно научиться решать проблемы, которые сейчас стоят перед учеными. Например, решение проблемы недостатка донорских органов достигается пропагандой. Учёные стараются донести до сознания людей, что пожертвование органов после смерти может спасти чью-то жизнь. Также эту проблему решают путем разработки искусственных органов и ксенотрансплантацией. Но нужно понимать, что при последнем пути решения есть риск переноса вирусов, бактерий и микроорганизмов от животных к человеку. Также важную роль играет фактор иммунологической несовместимости и этико-психологический фактор. Далеко не каждый человек способен нормально принять пересадку чужого органа.

Перспективы развития трансплантологии тесно связаны с преодолением антигенной несовместимости для пересадки органов животных человеку. Это 
помогло бы решить проблему дефицита донорских органов. В этом направлении проводятся интенсивные и довольно успешные исследования по выращиванию трансгенных свиней с набором HLA-антигенов, близким к человеческому, и изысканию наиболее эффективных средств для предотвращения реакции отторжения ксенотрансплантанта.

Тем не менее, ксенотрансплантология создает возможности для лечения широкого круга тяжелых заболеваний, таких как сахарный диабет, терминальная стадия почечной и сердечной недостаточности.

Заключение. Учёные считают, что трансплантология является одним из современных и активно развивающихся разделов медицины. Это медицина будущего, которая уже сейчас дает невероятный шанс на выздоровление и полноценную жизнь человеку с заболеваниями органов и тканей, который еще столетие назад был бы обречен. Трансплантология появилась не так давно, но уже имеет большие успехи. Сегодня хирурги могут пересадить человеку почки, печень, сердце, легкие, поджелудочную железу, щитовидную и околощитовидную железы, роговицу и селезенку.

Трансплантология - это перспективная отрасль медицины. Она за короткие сроки достигла огромных успехов и активно продолжает свое развитие. Как перспектива трансплантологии уже развивается биоинженерная технология по выращиванию органов. Её целью является создание различных полноценных жизнеспособных биологических органов для человека. Также активно развивается ксенотрансплантология, которая считается наиболее перспективным видом трансплантологии в будущем. Искусственные органы или органы другого биологического вида смогут спасти миллионы жизней.

\section{Список литературы}

1. Трансплантология: учебник / под ред. М.Ш. Хубутия. - М.: ГЭОТАРМедиа, 2016. (дата обращения 29.11.2020)

2. Биомедицинская этика: учебник / И. А. Шамов. - М.: ГЭОТАРМедиа, 2014. - 286 с.: ил. (дата обращения 29.11.2020)

3. Медицинское право: учебный комплекс для вузов / Сергеев Ю.Д. М.: ГЭОТАР-Медиа, 2008. - 784 с. (дата обращения 29.11.2020)

4. Мироненко, А. Каннибализм в конце 20 века. Трансплантология: этика, мораль, право / Врачебная газета. №11, ноябрь, 2000.- с. 16-17. (дата обращения 29.11.2020) 
5. Кэмпбелл, А. Медицинская этика / А. Кэмпбелл, Г. Джиллет. - М.: ГЭОТАР-Медиа, 2007. - 400 с. (дата обращения 29.11.2020)

6. Карпинетти А. Новое устройство, способное продлевать жизнеспособность трансплантата перед пересадкой сердца. / Электронный журнал, 24.02.2020. (дата обращения 29.11.2020) 